\title{
Kewirausahaan Berkelanjutan: Perspektif Teknologi Model Bisnis Untuk Meningkatkan Nilai Sosial Terhadap Lingkungan
}

\author{
Eka Purnama Harahap ${ }^{1}$, Ninda Lutfiani ${ }^{2}$, Muhammad Fachri Sholahuddin ${ }^{3}$ \\ Dosen Akuntansi Universitas Raharja ${ }^{1}$, Dosen Universitas Raharja ${ }^{2}$, Mahasiswa \\ Universitas Raharja Jurusan Komputerisasi Akuntansi ${ }^{3}$ \\ Jl. Jend. Sudirman No. 40, Modern Cikokol, Tangerang \\ ekapurnamaharahap@raharja.info ${ }^{1}$,nindalutfiani@raharja.info ${ }^{2}$, \\ muhammad.fachri@raharja.info ${ }^{3}$
}

\begin{abstract}
ABSTRAK
Artikel ini menyelidiki bagaimana orang-orang bisnis yang masuk akal menginstal inovasi canggih dalam rencana tindakan mereka untuk menggunakan penciptaan nilai sosial dan ekologis. Untuk tujuan ini, kita menarik pada sudut pandang alasan kelembagaan dari rencana tindakan yang dapat dipertahankan. Artikel ini menambahkan untuk menyelidiki model bisnis yang dapat dikelola dan perusahaan dengan menunjukkan bahwa kemajuan canggih memberdayakan desain baru dari rencana bagian tindakan yang dapat dipertahankan: penawaran campuran, penciptaan nilai integratif, dan tangkapan bernilai multidimensi. Juga, kita berbicara tentang komplementer dan strain dari alasan maju dan alasan pengelolaan yang menjelaskan dan memajukan hubungan antara ide-ide ini dalam pengaturan yang inovatif. Hal ini semakin menambah hipotesis perbaikan rencana tindakan yang dapat dikelola sebagai tanda-tanda berbagai alasan kelembagaan. Artikel ini menghasilkan konsekuensi pragmatis dengan menggambarkan hasil potensial dan kerugian dari kemajuan komputerisasi untuk merencanakan rencana tindakan yang dapat dipertahankan.
\end{abstract}

Kata Kunci : Komputerisasi, Inovasi, Model Bisnis

\begin{abstract}
This article investigates how sensible business people install sophisticated innovations in their action plans to use social and ecological value creation. To this end, we draw on the point of view of the institutional reasons of a defensible action plan. This article adds to investigate manageable and enterprise business models by showing that advanced advances empower new designs of defensible action part plans: mixed offerings, integrative value creation, and multidimensional value capture. Also, we are talking about complementary and strains of advanced reasons and management reasons that explain and advance the relationship between these ideas in innovative settings. This further adds to the hypothesis of improvement of an action plan that can be managed as signs of various institutional reasons. This article produces pragmatic consequences by describing the potential outcomes and disadvantages of computerized progress to plan a defensible action plan.
\end{abstract}

Keywords: Computerization, Innovation, Business Models 


\section{PENDAhULUAN}

Perusahaan telah diadakan sebagai jawaban yang mungkin untuk kesulitan sosial dan alam yang fantastis, misalnya, perubahan suasana dan memperluas ketidakseimbangan sosial. Visioner bisnis praktis dipandang sebagai penghibur kunci saat mereka memajukan upaya perbaikan yang dapat dikelola melalui penggunaan rencana tindakan yang layak secara moneter dan imajinatif yang membuat efek sosial dan ekologis yang positif. Meskipun demikian, pebisnis ekonomi menghadapi kesulitan ekstrem karena organisasi mereka perlu menggabungkan alasan ekologi, sosial, dan bisnis, yang sering kali terpisah mengenai kualitas, praktik, dan target mereka. Membuat nilai alam dan sosial dapat tetap dalam perbedaan brutal dengan alasan pasar bisnis yang mengatur manfaat moneter, menyebabkan ketegangan bagi orang-orang bisnis. Dalam hal strain meningkat ini tidak dapat diwakili dalam rencana rencana tindakan, mereka dapat mendorong ketidak steadiness bisnis apa lagi, merusak ekologis dan penciptaan nilai sosial. Selanjutnya, mengeksplorasi bagaimana visioner bisnis membuat lebih lanjut, menyesuaikan berbagai jenis nilai yang signifikan di dalam rencana tindakan mereka adalah zona permintaan yang tepat dan signifikan namun belum diselidiki secara memadai. Eksplorasi terlambat telah menerima pemikiran bahwa inovasi komputerisasi dapat kuat untuk menangani kesulitan yang dihadapi visioner bisnis ekonomis. Kecurigaan ini meluas pada batas terobosan digitalisasi yang menyesuaikan gagasan perusahaan selanjutnya, mengubah cara untuk menangani masalah maintainability. Secara khusus, inovasi canggih menawarkan peluang untuk praktik baru yang memberikan peluang inovatif dan memberdayakan kemajuan rencana aksi baru. Selanjutnya, ada kemungkinan energi koperasi antara usaha visioner bisnis untuk mengubah peristiwa ekonomi dan digitalisasi yang tampaknya masih tidak dapat diselidiki. Kami mengatasi lubang ini dengan memeriksa bagaimana visioner bisnis yang masuk akal memasukkan inovasi canggih ke dalam insentif, penciptaan harga, dan layak menangkap bagian dari model bisnis mereka.

Untuk tujuan ini, kami mengambil sudut pandang rasional institusional tentang rencana tindakan yang didukung. Alasan kelembagaan menyinggung set terseserisasi kualitas, keyakinan, dan praktek-praktek yang mengatur, memberdayakan, dan memaksa kegiatan. Rasionalitas kelembagaan menyinggung sistem dalam pandangan ini, rencana praktis tindakan yang diduga synthesis dari berbagai segmen, untuk menjadi spesifik, menawarkan, penciptaan harga diri, juga, harga menangkap, yang menunjukkan alam, sosial, dan bisnis kelembagaan rasional set kualitas, keyakinan, dan praktek-praktek yang mengatur, memberdayakan, dan memaksa kegiatan. Demikian juga, kami berpendapat bahwa digitalisasi melibatkan alasan maju yang berkembang yang memiliki hubungan khusus dengan alasan dukungan.

Penemuan kami menunjukkan bahwa inovasi canggih menjunjung tinggi peningkatan penawaran yang memadukan nilai ekologi, sosial, dan moneter. Selanjutnya, kemajuan lanjutan memberikan benda surgawi yang luar biasa untuk menghargai bagian penciptaan, mempertimbangkan praktek perbaikan jaringan, penciptaan bersama, dan koordinasi mitra yang lebih luas. Penggunaan kemajuan komputerisasi juga dapat mendorong multidimensional layak menangkap karena memberdayakan bergoyang komplementer, fleksibilitas nilai sosio environmental, dan layak meluap. Selain itu, penemuan memberikan pengalaman ke dalam potensi alasan terkait strain di dalam dan antara segmen rencana aksi.

Artikel ini menambah bisnis yang dapat dipertahankan dan rencana penelitian tindakan dengan mengenali bagaimana kemajuan komputerisasi dapat digunakan untuk membuat harga diri sosio environmental. Kami menambah eksplorasi kontemporer dengan menjelaskan pengaturan baru dari rencana segmen aksi yang wajar yang diberdayakan oleh kemajuan lanjutan. Eksplorasi kami berbicara tentang komplementer dan tekanan mempertahankan dan inovasi komputerisasi, menambah pemahaman yang lebih mendalam tentang bagaimana visioner bisnis menambah peristiwa yang masuk akal. Demikian juga, dengan bersaing untuk alasan komputerisasi meningkat, kita menambah kemajuan hipotesis dari sudut pandang rasional kelembagaan pada rencana tindakan yang wajar dan konvergensi sudut pandang maju dan masuk akal di dalam banjir eksplorasi ini. Kami menutup dengan konsekuensi praktis untuk visioner bisnis praktis seperti jalan untuk eksplorasi di masa depan. 


\section{KERANGKA TEORITIS}

\subsection{Perspektif logika kelembagaan tentang bisnis berkelanjutan model}

Gagasan rasionalitas kelembagaan dimulai dari karya dasar Friedland dan Alford yang mengakui kehadiran beberapa perusahaan (misalnya pasar, agama, atau keluarga) yang masing-masing memiliki alasan khusus mereka sendiri. Alasan-alasan ini menyinggung kerangka kepentingan antara subjective termasuk kualitas, keyakinan, dan standar yang menempatkan, memberdayakan, dan mewajibkan kegiatan. Alasan kelembagaan memberikan keunggulan untuk menilai apa yang signifikan dan berdampak pada pengembangan tujuan (Friedland, 2018a), dengan cara ini, membentuk orang dan asosiasi sebagai kualitas dan keyakinan mereka mengelola apa yang dianggap layak dicari. Alasan utama metodologi ini adalah bahwa berbagai alasan menggiling pergi secara bersamaan, mungkin mendorong komplementer dan tekanan antara alasan. Pemeriksaan yang sedang berlangsung telah membedakan sudut pandang alasan kelembagaan sebagai cara yang produktif untuk menangani penelitian bagaimana kerangka arti ekologis, sosial, dan bisnis berdampak pada kebijakan strategis dan rencana tindakan individu.

Rencana aksi ekonomis disangka terdiri dari pengaturan yang saling terkait dari bagian-bagian yang diambil bersama-sama menggambarkan latihan penciptaan bernilai usaha. Komponen-komponen ini mengacu pada arsitektur usaha, mencerminkan bagaimana sebuah organisasi berfungsi untuk mencapai tujuannya juga, mengungkapkan hubungan bawaan dari nilai yang signifikan dan juga, kerinduan terkait organisasi. Bagianbagian dari rencana tindakan dilambangkan dalam pemahaman orang-orang bisnis yang melayani heuristik atau kapasitas akun, muncul dalam keingintahuan substansial dan visual-dicetak, dan diperintahkan melalui latihan jelas. Tulisan ini mengkonsepkan rencana tindakan yang terdiri dari insentif, penciptaan harga diri, dan layak menangkap bagianbagian yang dibentuk oleh dan menunjukkan alasan kelembagaan yang berbeda.

Sementara ide bisnis bernilai signifikan yang berkembang di sekitar manfaat moneter menggambarkan rencana tindakan reguler, rencana tindakan yang dapat dikelola melewati manfaat terkait uang sederhana dan selanjutnya menggarisbawahi harga apa yang lebih, keyakinan ekologis dan alasan sosial. Kualitas ekologis, misalnya, kesempurnaan alam dan limbah menurun atau kualitas sosial seperti kemajuan, rasa hormat, atau penguatan umat manusia memancarkan dari alasan-alasan kelembagaan ini. Bagian dari alasan non-bisnis dapat dikoordinasikan di semua segmen rencana aksi. Membangun banyak alasan dalam kelompok bintang lintas ras dibayangkan mendorong komplementer dan strain, memberikan bisnis praktis yang menunjukkan usaha yang tidak dapat diprediksi. Oleh karena itu, pelaku bisnis memainkan peran penting dalam menafsirkan, mengkoordinasikan, juga, mencampur alasan kelembagaan yang dapat diakses ke dalam model bisnis. Misalnya, visioner bisnis yang dapat dipertahankan muncul untuk membangun saran berharga yang berkembang di sekitar bagaimana sudut pandang pengelolaan memajukan sifat item. Kasus yang berbeda memberikan pengalaman ke dalam bagaimana orang-orang bisnis layak menangkap pekerjaan melewati manfaat dengan sengaja berpikir tentang pengurangan limbah dan perbaikan jaringan atau kombinasi aset yang wajar ke dalam penciptaan layak.

\subsection{Logika Digitalisasi Yang Muncul}

Digitalisasi menyinggung alokasi atau perluasan pemanfaatan inovasi canggih, misalnya, komputasi terdistribusi, tenaga otak buatan manusia, pencetakan 3D, atau pendaftaran portabel oleh pemerintah, bisnis, atau asosiasi. Sifat luar biasa dari kemajuan canggih membuat keterjangkauan terkomputerisasi yang menyinggung peluang tambahan untuk 
aktivitas yang sesuai dengan klien tertentu atau pengaturan penggunaan yang dapat dimanfaatkan oleh penghibur, misalnya, visioner bisnis.

Siklus perubahan terkomputerisasi menunjukkan dalam kursus kelembagaan baru tindakan, mencapai kualitas baru, berlatih, dan struktur yang mempengaruhi aturan mengatur permainan dan menantang kontemporer alasan benda langit. Kursus tindakan ini menggabungkan, misalnya, oleh dan besar diakui dan disesuaikan modul komputerisasi seperti kerangka kerja ERP, atau kerangka kerja komputerisasi pengaturan standar yang mengatur asosiasi penghibur, misalnya, tahap item dan inovasi blockchain. Pada dasarnya, kemajuan komputerisasi yang sangat menarik ini juga mempengaruhi rencana tindakan. Para peneliti berpendapat bahwa keterjangkauan terkomputerisasi akan dengan kerangka kerja canggih dan modul memperluas pilihan dan menghasilkan jalur baru untuk membuat, menyampaikan, dan menangkap senilai. Perubahan tindakan moneter mendorong model bisnis yang sangat baru yang membutuhkan kapasitas hirarkis eksplisit untuk diakui secara efektif.

Dengan menyajikan praktek-praktek baru, kualitas, dan struktur, kemajuan komputerisasi tampaknya memiliki mereka sendiri namun pada saat yang sama meningkat alasan yang bertepatan dengan dan mengubah pemahaman dan otorisasi rasional kelembagaan lainnya. Sesuai pekerjaan yang sedang berlangsung, digitalisasi berkembang di sekitar ide-ide jaringan, antarmuka, penerimaan, ketersediaan, variabilitas, dan generativitas. Kami berpendapat bahwa alasan komputerisasi berisi pikiran-pikiran ini dan dengan demikian mempertimbangkan praktek-praktek baru dapat ditambahkan ke koleksi potensi alasan yang dibentuk pada tingkat rencana tindakan. Meskipun demikian, bagaimana alasan berkembang ini berkomunikasi dengan alasan-alasan yang ada, yaitu hubungan lawan dan sinergis antara alasan maju dan non digital, adalah wilayah yang signifikan untuk eksplorasi tambahan.

\section{METODE}

Menggambar pada eksplorasi masa lalu pada rencana tindakan dalam bisnis ekonomi, kami memilih untuk menerapkan metodologi kualitatif untuk menganalisis gestalt dari tertanamnya teknologi advanced dalam model bisnis pengusaha berkelanjutan. Menerapkan desain penelitian kualitatif memungkinkan studi yang memadai dan deskripsi hubungan kompleks komponen model bisnis individu, representation mereka, dan terwujudnya beberapa logika kelembagaan. Selanjutnya, desain penelitian kualitatif direkomendasikan untuk studi logika kelembagaan. Kami mengikuti pendekatan sistematis yang memungkinkan keterlibatan induktif dengan information dalam kerangka teoritis.

\subsection{Pengumpulan Data}

Kami mengumpulkan informasi mengikuti sistem pemeriksaan hipotesis yang mendukung bermacam-macam bersama dan pengkodean informasi dan memperhitungkan penentuan anggota studi seperti yang ditunjukkan oleh ide-ide yang berkembang di dalam siklus eksplorasi. Sesuai dengan hipotesis membumi semakin dekat, kami memulai bermacam-macam informasi kami dengan pertanyaan eksplorasi yang lebih luas yang bermaksud untuk memeriksa tindakan orangorang bisnis yang wajar yang diduduki dengan penciptaan nilai ekonomi biologis dan sosial. Untuk tujuan ini, kami menyaring entri dan harapan persaingan pengejaran baru Austria yang memusatkan perhatian pada tugas-tugas ekologis dan sosial seperti program agen persegeraan yang berlaku untuk membedakan orang-orang bisnis yang wajar. Kami mengenali dua puluh orang bisnis yang senang tertarik pada penyelidikan. Setelah menyelesaikan pertemuan yang mendasarinya, kami memulai metode pengkodean dan secara induktif mengenali pentingnya sudut pandang lanjutan di dalam rencana tindakan enam orang bisnis yang diperiksa. Oleh karena itu, dalam putaran kedua bermacam-macam informasi, kami sekali lagi bergerak menuju anggota persaingan pengejaran baru dan mempercepat proyek agen untuk memperluas contoh yang mendasarinya dengan kasus 
tambahan yang sesuai dengan pusat pemeriksaan yang disesuaikan. Kami terus menambahkan orang-orang bisnis ke contoh kami sampai tidak ada ide-ide baru lebih lanjut naik dan kemudian pencelupan dihargai telah dicapai . Sistem pemeriksaan ini memungkinkan kami untuk membuat contoh yang jelas dari lima belas kasus.

Memperluas gagasan bahwa rencana aksi dibicarakan dalam berbagai jenis barang antik yang jelas dan dicetak secara visual dan dikomunikasikan melalui cerita, kami mengumpulkan informasi penting dan opsional yang luas. Kami memimpin hingga tiga pertemuan semiterorganisir dengan orang-orang bisnis yang didukung yang mengamankan pengalaman dan inspirasi mereka sendiri, siklus penciptaan petualangan, rekayasa yang berguna, selanjutnya, memvisualisasikan kemungkinan peristiwa di masa depan. Setiap pertemuan berlangsung di suatu tempat dalam kisaran 45 dan 90 menit. Demikian juga, kami mengumpulkan informasi dari berbagai sumber, misalnya, halaman arahan, entri blog, data media berbasis web, artikel kertas, sama seperti rekaman penulis. Kami menganonimkan ini dalam dan luar kasus memanfaatkan huruf-huruf yang dipilih dari huruf Yunani diatur untuk meng-upgrade kejernihan.

\subsection{Analisis Data}

Kami menerapkan tindakan investigasi informasi yang diatur secara induktif dan multilangkah tergantung pada kontemplasi yang dimulai dari pendekatan hipotesis berbumi. Siklus ini digambarkan oleh komitmen berulang dengan bahan kasar yang dikumpulkan, kode dan ide yang berkembang, sama seperti ide hipotesis perusahaan yang masuk akal, rencana penelitian tindakan, juga, alasan kelembagaan. Pada langkah awal, setiap spesialis sangat tertarik dengan informasi menyeluruh dan bagian kode terbuka yang penting untuk bergerak menuju pertanyaan pemeriksaan. Dengan memeriksa sifat bersama antara kasus, kami berbicara tentang kontras dan kemungkinan kode untuk menggabungkan entri kode terbuka ini ke dalam kode permintaan pertama. Kode permintaan pertama pada saat itu memberi pendirian untuk lebih banyak hipotesis didorong topik permintaan kedua, yang, pada gilirannya, dirakit menjadi pengukuran total. Ini adalah siklus nonlinear, pergi ke sana kemari antara coding, gathering, terlebih lagi, percakapan hipotesis. Sesuai dengan pemeriksaan sebelumnya, cara komponensial untuk menangani rencana tindakan menawarkan arah penjelasan dimana kode dapat diperiksa dan diuraikan Kami menyajikan konsekuensi terakhir dari metodologi pengkodean dalam struktur informasi dalam.

\section{TEMUAN}

\subsection{Proporsi Nilai Campuran}

Penemuan kami mengungkap bahwa visioner bisnis menggunakan kemajuan terkomputerisasi untuk menciptakan insentif campuran bagi mitra mereka. Untuk mulai dengan, alasan komputerisasi memungkinkan untuk mengkatalisis penciptaan harga sosio environmental dan, kedua, memberdayakan visioner bisnis untuk mendirikan penawaran yang mengkonsolidasikan ekologi, sosial, dan penghargaan moneter untuk mitra mereka.

Jaminan penting dari kemajuan komputerisasi yang diilustrasikan oleh visioner bisnis ekonomis adalah kapasitas mereka untuk membuat latihan yang dapat didukung semua lebih luas diakses, tersedia, dan dapat dilakukan. Visioner bisnis mengakui bagian-bagian inovatif dari model bisnis mereka sebagai aset integral untuk mengkatalisis metode hidup yang lebih produktif.

"Anda tahu, kami memiliki inovasi sekarang, namun tampaknya dunia belum hidup seperti 200 tahun yang lalu. Anda tahu, kami memiliki semua gadget dan situs serbaguna ini dan ketersediaan web, namun kami pasti tidak memanfaatkannya untuk merampingkan kehidupan kami."(Beta).

Dengan demikian, alasan dari beberapa rekomendasi layak visioner bisnis yang didukung adalah untuk menjamin pemanfaatan kontribusi mereka yang bermanfaat. Tahap komputerisasi, khususnya, mengizinkan asosiasi yang kuat dan mahir sebelumnya terlepas secara fleksibel dan permintaan, di sepanjang garis-garis ini mendukung penyebaran insentif sosial dan ekologis seperti yang dirujuk oleh salah satu anggota kami.

"Ini adalah pasar canggih di mana kami membawa pembuat makanan teritorial apalagi, pembeli metropolitan bersama-sama. Sampai sekarang, ada 400 perusahaan kecil dan swasta yang perlu membawa barang-barang mereka kepada Anda dan saya juga, kami berhati-hati untuk menjamin bahwa mereka menemukan jalan mereka dari tempat terbuka lebar ke kota." (Iota) 
Tabel 1 (Tabel 1)

Penggambaran kasus dan informasi yang dikumpulkan.

\begin{tabular}{|c|c|c|c|}
\hline $\begin{array}{c}\text { Nama } \\
\text { Variabel }\end{array}$ & Deskripsi & $\begin{array}{c}\text { Jumlah } \\
\text { Wawancara }\end{array}$ & Data tambahan \\
\hline Alpha & $\begin{array}{l}\text { Menawarkan jawaban pemrograman untuk jaringan } \\
\text { untuk menyaring dan mengawasi kendaraan umum } \\
\text { termasuk aplikasi untuk klien akhir. Informasi yang } \\
\text { diberikan oleh klien adalah pendirian untuk } \\
\text { memodifikasi kontribusi lalu lintas menghindari } \\
\text { kemacetan dan membuat transportasi dapat diakses di } \\
\text { mana paling diperlukan. }\end{array}$ & 1 & $\begin{array}{l}\text { Homepage, } \\
\text { newsletter }\end{array}$ \\
\hline Beta & $\begin{array}{l}\text { Menyediakan stage online untuk berbagi buku antara } \\
\text { pengguna dengan sistem kredit worked in untuk } \\
\text { memantau aktivitas dan pengalaman pengguna. }\end{array}$ & 2 & $\begin{array}{l}\text { Homepage, } \\
\text { social media, } \\
\text { videos, informal } \\
\text { talks }\end{array}$ \\
\hline Gamma & $\begin{array}{l}\text { Mengembangkan sistem pompa surya untuk } \\
\text { menawarkan pasokan air bersih dan murah untuk } \\
\text { daerah yang terkena dampak kemiskinan. Dilengkapi } \\
\text { dengan platform online dan komunitas yang } \\
\text { menyelenggarakan proyek air di seluruh dunia. }\end{array}$ & 1 & $\begin{array}{l}\text { Homepage, } \\
\text { blog, videos, } \\
\text { informal talks }\end{array}$ \\
\hline Delta & $\begin{array}{l}\text { Mendistribusikan solusi aplikasi untuk } \\
\text { memungkinkan orang tua mengatur janji temu medis } \\
\text { dan perawatan awal jarak jauh melalui saluran } \\
\text { computerized. }\end{array}$ & 1 & Homepage \\
\hline Epsilon & $\begin{array}{l}\text { Stage online yang menghubungkan petani } \\
\text { bersertifikat lingkungan dan produk mereka dengan } \\
\text { pembeli potensial mengurangi potensi limbah } \\
\text { (penjualan hanya terjadi jika ada permintaan untuk } \\
\text { bagian dari hewan) dan mempromosikan petani lokal. }\end{array}$ & 1 & $\begin{array}{l}\text { Homepage, } \\
\text { blog, social } \\
\text { media }\end{array}$ \\
\hline Zeta & $\begin{array}{l}\text { Sebuah kebun sayur web based gamified (CO2 netral } \\
\text { dan bersertifikat lingkungan). Pengguna dapat } \\
\text { merancang taman dan menanam secara advanced dan } \\
\text { membudidayakan berbagai sayuran, yang kemudian } \\
\text { ditanam oleh perusahaan dan diangkut ke pelanggan. }\end{array}$ & 1 & $\begin{array}{l}\text { Homepage, } \\
\text { blog, social } \\
\text { media, videos, } \\
\text { newspaper } \\
\text { articles }\end{array}$ \\
\hline Iota & $\begin{array}{l}\text { Pasar petani advanced. Stage online menghubungkan } \\
\text { petani lokal dan produk mereka (misalnya, buah, } \\
\text { sayuran, permen, minuman, dll.) dan pembeli } \\
\text { potensial memperkuat produksi lokal dan ramah } \\
\text { lingkungan. }\end{array}$ & 1 & $\begin{array}{l}\text { Homepage, } \\
\text { podcast, blog, } \\
\text { newspaper } \\
\text { articles }\end{array}$ \\
\hline
\end{tabular}




\begin{tabular}{|l|l|l|l|}
\hline Kappa & $\begin{array}{l}\text { Mengembangkan solusi media sosial online yang } \\
\text { bertujuan untuk meningkatkan kontak fisik antara } \\
\text { orang-orang yang menangkal isolasi sosial. }\end{array}$ & 3 & $\begin{array}{l}\text { Homepage, } \\
\text { observations, } \\
\text { informal talks }\end{array}$ \\
\hline Lambda & $\begin{array}{l}\text { Solusi perangkat lunak komprehensif untuk } \\
\text { mengelola dan memelihara stasiun untuk e-kendaraan }\end{array}$ & 1 & Homepage, videos \\
\hline Omikron & $\begin{array}{l}\text { Menawarkan stage perangkat lunak dan metode } \\
\text { pencocokan berbasis ilmiah untuk menemukan } \\
\text { pengasuh yang ideal bagi orang-orang yang } \\
\text { membutuhkan perawatan. Bertujuan untuk } \\
\text { mengurangi stres sosial dan untuk meningkatkan } \\
\text { hubungan perawatan pihak-pihak yang terlibat. }\end{array}$ & 1 & $\begin{array}{l}\text { Homepage, videos, } \\
\text { informal talks, } \\
\text { newspaper articles }\end{array}$ \\
\hline Rho & $\begin{array}{l}\text { Stage pembelajaran online yang dikombinasikan } \\
\text { dengan unit pembelajaran termasuk perangkat } \\
\text { pencetakan 3D yang memfasilitasi efek pendidikan di } \\
\text { bidang keberlanjutan. }\end{array}$ & 2 & $\begin{array}{l}\text { Homepage, } \\
\text { observations }\end{array}$ \\
\hline Sigma & $\begin{array}{l}\text { Sebuah stage crowdfunding dan manajemen proyek } \\
\text { yang mengkhususkan diri dalam proyek-proyek } \\
\text { lingkungan dan bertujuan untuk mengurangi } \\
\text { partisipasi sipil dan nilai-nilai demokrasi. }\end{array}$ & 1 & $\begin{array}{l}\text { Homepage, blog, } \\
\text { information on } \\
\text { past funded } \\
\text { projects }\end{array}$ \\
\hline Tau & $\begin{array}{l}\text { Pasar online yang mengkhususkan produk provincial, } \\
\text { berkelanjutan dan amal serta informasi komprehensif } \\
\text { dan transparan yang sesuai mengenai produk. } \\
\text { akomodasi hijau. Sistem kredit menilai penawaran } \\
\text { pelanggan yang berbeda dilengkapi dengan peringkat }\end{array}$ & 1 & $\begin{array}{l}\text { Homepage, social } \\
\text { media, videos }\end{array}$ \\
\hline $\begin{array}{l}\text { Pemasok lampu dan tokoh lokal dan cukup } \\
\text { diproduksi. Melalui kuesioner online dan realitas } \\
\text { virtual, pelanggan dapat melengkapi rumah mereka. }\end{array}$ & $\begin{array}{l}\text { Homepage, blog } \\
\text { observations, blog, } \\
\text { informal talks }\end{array}$ \\
\hline
\end{tabular}

Tabel 1. Penggambaran kasus dan informasi yang dikumpulkan.

Pengusaha lain menguraikan kesulitan menemukan, mengevaluasi, dan akhirnya membeli barang-barang yang ramah lingkungan dan diproduksi secara lokal. Oleh karena itu, pasar online mereka bertujuan untuk memberikan alternatif yang lebih baik dan lebih nyaman untuk membeli produk berkelanjutan di berbagai toko. Konsep peningkatan kenyamanan melalui pasar advanced ini juga telah diperkenalkan ke jenis produk lain dalam sampel kami (misalnya, berbagai jenis makanan atau buku). Pengusaha lain menawarkan cell phone dan aplikasi web yang memberikan efisiensi bagi pemangku kepentingan dengan menganalisis information pengguna dan merekomendasikan alternatif yang lebih berkelanjutan. Misalnya, Alpha menawarkan aplikasi yang menyediakan information constant penggunanya yang menggambarkan perilaku mobilitas mereka dan konsekuensi ekologis masing-masing. Selain itu, aplikasi ini langsung menyarankan sarana transportasi ramah lingkungan lainnya untuk memicu perubahan perilaku segera. Aplikasi ini berfungsi sebagai katalis untuk proposisi nilai sosial lingkungan dengan secara bersamaan membuat pengguna menyadari keberadaan alternatif ekologis dan meningkatkan aksesibilitas dan kenyamanan alternatif ini. 
Integrasi logika advanced memungkinkan pengusaha untuk berhasil menggabungkan proposisi nilai lingkungan, sosial, dan ekonomi. Dengan menyematkan teknologi advanced pengusaha dapat menawarkan produk dan layanan yang berkelanjutan dengan harga yang kompetitif. Salah satu pengusaha, misalnya, menyatakan bahwa pasar digitalnya memungkinkan petani bersertifikat lingkungan dan pelanggan potensial untuk berdagang dengan nyaman, yang mengarah pada pengurangan dan pencegahan limbah yang tidak perlu, sambil secara bersamaan mengamati hak-hak hewan dalam produksi daging. Oleh karena itu, pasar computerized memungkinkan transaksi yang efisien dengan memastikan keuntungan finansial bagi produsen meskipun menawarkan harga yang wajar, dengan demikian, menggabungkan nilai ekonomi.

\subsection{Pembuatan nilai integratif}

Temuan kami menunjukkan bahwa teknologi advanced berpotensi meningkatkan konektivitas aktor dalam komponen penciptaan nilai. Kami mengidentifikasi tiga, sering saling terkait, set praktik membangun komunitas, penciptaan bersama, dan memperluas integrasi pemangku kepentingan e di mana logika advanced memfasilitasi pembukaan batas-batas penciptaan nilai, membuat komponen ini lebih integratif.

Para pengusaha sering berusaha untuk membentuk komunitas yang hidup di sekitar tantangan sosio environmental yang ingin mereka tangani, misalnya, melalui pembuatan dan penyediaan pusat informasi, discussion/papan on the web, stage, atau jaringan computerized dan alat komunikasi lainnya. Salah satu cara untuk mendekati ini ditawarkan oleh Sigma, yang bertujuan untuk memungkinkan partisipasi sipil dalam proyek lingkungan publik melalui komunitas online-nya. Untuk ini, Sigma mendirikan stage crowdfunding dengan alat jaringan:

"Kami mempertimbangkan untuk lebih berfokus pada pembangunan komunitas karena ide dasarnya adalah alat sederhana untuk partisipasi warga dan integrasi pelanggan. Karena itu sebenarnya resep untuk sukses. Seperti yang dapat kita lihat dari proyek yang sedang berlangsung, kebutuhan akan komunitas sangat banyak di sana. Kami pasti memiliki sudah lebih memantapkan diri sebagai stage crowdfunding bagi pengguna untuk mendukung proyek keberlanjutan".

Komunitas-komunitas ini, misalnya, digambarkan melalui representasi kartografi advanced yang menunjukkan di mana masing-masing aktor berada, bagaimana mereka terhubung, dan apa yang mereka kontribusikan kepada komunitas (misalnya berbagi informasi, mengelola proyek tambahan, dll.).

\begin{tabular}{|l|l|l|}
\hline Kode Urutan Pertama & Tema Urutan Kedua & Dimensi Agregat \\
\hline
\end{tabular}

Gambar. 1. Struktur data 


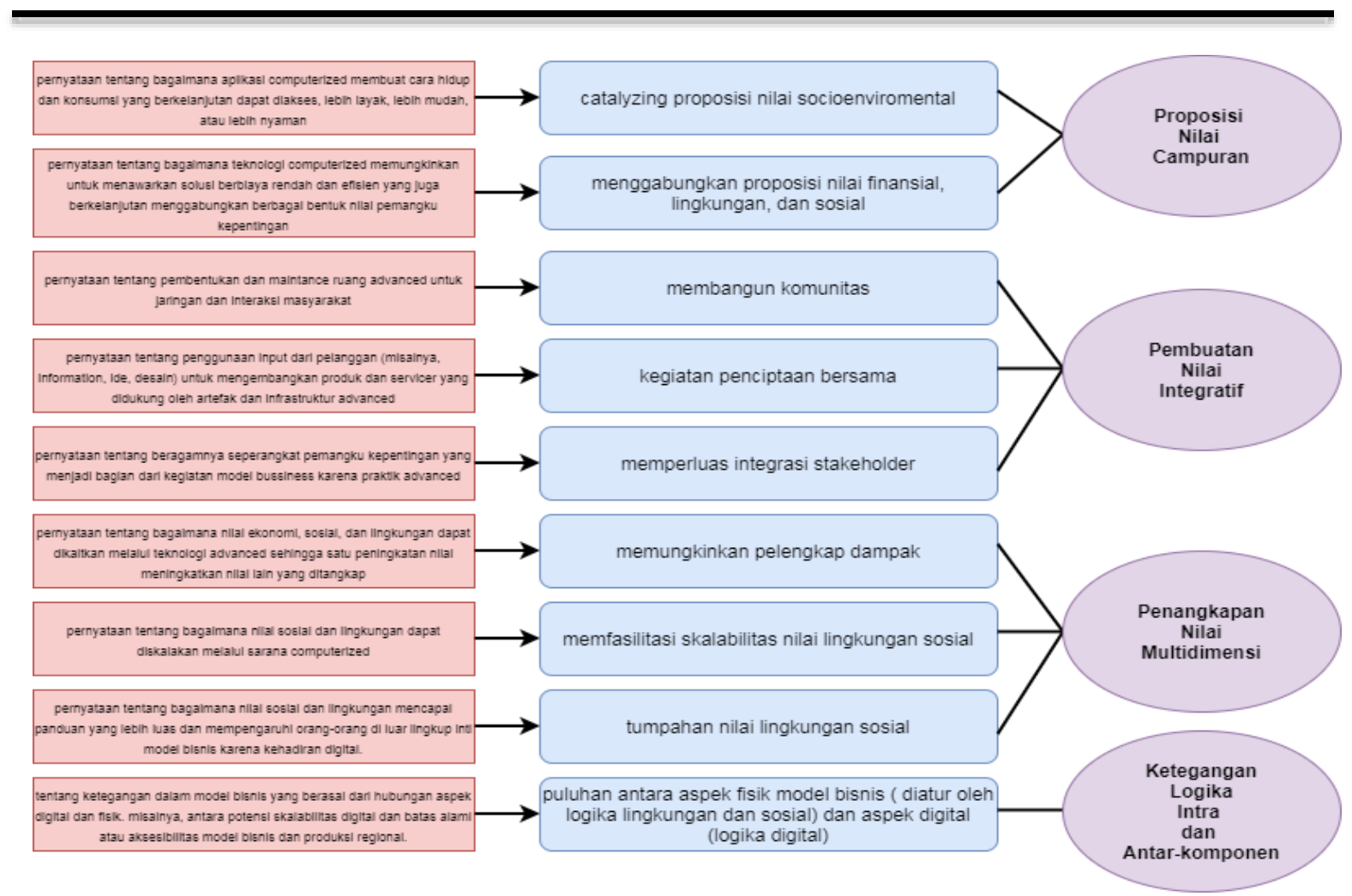

Selain itu, beberapa pengusaha menggunakan teknologi computerized untuk memfasilitasi penciptaan bersama dengan penggunanya seperti yang dicontohkan oleh pernyataan misi Beta "Didukung oleh komunitas e dikuratori dan dipelihara oleh teknologi". Kami menemukan bahwa untuk mewujudkan layanan online khusus yang didasarkan pada konektivitas, pemanfaatan sumber daya individu pelanggan adalah basic. Ko-kreasi nilai yang diaktifkan dengan cara advanced ini dapat mencakup sumber daya berwujud (misalnya, berbagi objek seperti buku), tetapi juga sumber daya pengguna yang tidak berwujud. Misalnya, pengguna bertindak sebagai pembuat konten untuk blog dan situs web yang menguntungkan komunitas dan dengan demikian bisnis (Rho) atau mengartikulasikan ide untuk proyek publik-swasta umum di stage crowdfunding (Sigma). Dalam veine ini, Zeta memungkinkan pelanggan untuk secara advanced merancang lahan pertanian mereka sendiri di mana mereka memilih dan membudidayakan tanaman, sayuran, dan buah-buahan melalui antarmuka pengguna yang gamified. Instruksi ini kemudian diwujudkan oleh perusahaan dan produk yang diproduksi secara lokal dikirim ke pelanggan. Dengan demikian, usaha kewirausahaan bertindak sebagai perantara computerized mentransfer input advanced ke dalam yield fisik. Selain integrasi aktif pengguna dalam pembuatan nilai, berbagai perusahaan menganalisis information pengguna untuk mengembangkan penawaran baru atau meningkatkan penawaran yang ada (misalnya, Alpha, Lambda, Epsilon, Omega).

Terkait dengan upaya ini dan meresapi gagasan membangun komunitas dan penciptaan bersama adalah integrasi serangkaian stakeholder yang semakin beragam melampaui pelanggan dan pemasok. Melalui jaringan computerized, pengusaha berkelanjutan dapat ber inklusif ketika membangun jaringan penciptaan nilai advanced mereka seperti yang ditunjukkan oleh kutipan berikut:

"Jaringan worldwide kami mengundang individu, bisnis lokal, LSM, sukarelawan, dan pendukung untuk bergabung. Setiap anggota memiliki akses free ke informasi tentang pelaksanaan dan pengelolaan proyek pasokan air. Semua orang bisa menjadi bagian dari itu!" (Gamma). 


\subsection{Penangkapan nilai multidimensi}

Dalam hal komponen penangkapan nilai, logika advanced memungkinkan pengusaha untuk memungkinkan pelengkap dampak (yaitu, terjalinnya penangkapan nilai lingkungan dan keuangan sosial), mendukung skalabilitas nilai lingkungan sosial, dan memfasilitasi tumpahan nilai lingkungan sosial melalui sarana computerized. Ini mengarah pada penangkapan nilai multidimensi dengan menambahkan beberapa bentuk nilai serta batas dan skala nilai ditangkap.

Temuan menunjukkan bahwa logika advanced mendukung resolusi tantangan menggabungkan penangkapan nilai sosio environmental dan ekonomis. Pengusaha menyatakan bahwa realisasi satu nilai sering sesuai dengan peningkatan yang lain dan sebaliknya (misalnya, Sigma, Phi). Hubungan komplementer ini withering jelas dalam model bisnis yang melakukan fungsi perantara untuk menghubungkan berbagai aktor (stage advanced). Di sini, setiap layanan atau produk yang dijual memerlukan penangkapan nilai sosial dan/atau lingkungan (misalnya, stage pemesanan untuk akomodasi berkelanjutan) sambil secara bersamaan memungkinkan penangkapan nilai keuangan (misalnya, melalui biaya komisi pengisian). Layanan crowdfunding untuk proyek berkelanjutan memungkinkan pelengkap dampak serupa. Mereka meningkatkan kesadaran masyarakat akan proyek-proyek mereka yang dapat didanai melalui saluran computerized yang memungkinkan pengusaha untuk mengkurasi proyek dengan dampak potensial tertinggi. Setiap tindakan terkait dari orang banyak apakah itu klik sederhana, sumbangan, atau janji e mengarah pada penangkapan nilai keuangan dan sosio environmental. Oleh karena itu, berbagai bentuk nilai tidak dikotomi dalam model bisnis ini tetapi dapat saling melengkapi ketika terjalin melalui computerized berarti.

Kami lebih lanjut mengidentifikasi bagaimana pengusaha memanfaatkan karakteristik solusi advanced untuk memfasilitasi skalabilitas nilai lingkungan sosial. Generativitas aspek computerized model bisnis memungkinkan pengusaha untuk "memasukkan persyaratan kegunaan dan pendapat pengguna" (Kappa) untuk menyesuaikan produk mereka. Aplikasi dan infrastruktur advanced dapat disesuaikan dan dapat diperluas terhadap produk dan layanan baru. Selain itu, mereka ditandai dengan move yang tampaknya mudah ke pasar lain (misalnya, Epsilon, Zeta). Aspek-aspek ini memungkinkan skalabilitas beberapa bentuk nilai sebagaimana dibubutangkan oleh komentar berikut:

"Saya ingin mencari model, yang memiliki dampak positif pada lingkungan saya tetapi juga memiliki atribut klasik dari fire up. Dengan individualized structure lain, itu dapat diskalakan seperti kasus modular ventura. Saya ingin menunjukkan bahwa keduanya mungkin terjadi pada abad ke-21." (Phi).

Selain itu, temuan menunjukkan bahwa pengusaha berkelanjutan meningkatkan kesadaran dan pendidikan mengenai masalah keberlanjutan, yang seringkali merupakan hasil tambahan dari model bisnis mereka. Kami menyebut nilai ini tumpah karena tidak eksklusif untuk kelompok target langsung tetapi berpotensi tumpah ke berbagai pemangku kepentingan yang mengarah pada penangkapan nilai lingkungan sosial tambahan untuk bisnis. Untuk mencapai tumpahan tersebut, pengusaha berkelanjutan sebagian besar mengandalkan media advanced seperti situs web, blog, media sosial, aktivitas jaringan di stage masing-masing, atau pembinaan komunitas on the web. Karena kehadiran advanced ini, para pengusaha melakukan "pekerjaan pendidikan" (Epsilon) atau "bekerja pada tingkat kesadaran" (Tau) dan berusaha untuk "memulai gerakan" (Beta), erat terkait dengan pembangunan masyarakat sebagai bagian dari penciptaan nilai Komponen. Kutipan berikut ini lebih lanjut menggambarkan gagasan ini:

"Jadi, kami belum cukup di mana kami ingin berada dalam hal keberlanjutan, tetapi saya masih berpikir bahwa kami telah menciptakan kesadaran tertentu untuk masalah-masalah tersebut." (Tau).

"Saya pikir ini terjadi secara otomatis karena komunitas kami. Setiap orang yang datang ke situs web kami harus berurusan dengan topik untuk lebih baik atau lebih buruk. Semua orang yang melihat iklan kami akan menghubungi topik tersebut. Dan jika mereka berpikir tentang hal itu, itu mungkin tinggal di belakang pikiran mereka." (Phi). 


\subsection{Ketegangan logika antar-dan intra-componential}

Kami juga mengidentifikasi tantangan dalam kaitannya dengan menggabungkan logika lingkungan, sosial, dan computerized yang dinyatakan dalam ketegangan logika antar dan intra komponal. Ketegangan besar antara nilai-nilai sosial dan lingkungan dan logika computerized berasal dari tabrakan aspek advanced dan fisik model bisnis. Computerized berarti secara teoritis memberikan potensi skalabilitas tak terbatas dan, seperti yang ditunjukkan, memungkinkan untuk menskalakan penangkapan berbagai bentuk nilai dan memungkinkan komplementaritas dampak. Namun ada pembatasan yang muncul dari batas-batas alam yang diberikan yang diatur oleh logika sosial dan lingkungan. Produk dan layanan sering memiliki sifat fisik dan membutuhkan sumber daya fisik untuk menghasilkan. Penciptaan nilai yang dimaksudkan, dengan demikian, harus mempertimbangkan logika sosial dan lingkungan.

Contoh dari tantangan ini adalah kontradiksi antara aksesibilitas online dan kedaerahan. Solusi advanced berpotensi kurang terkendala oleh pertimbangan geografis, tetapi mereka dapat menantang gagasan produksi dan konsumsi local. Pengusaha yang mencari kedaerahan sering bertujuan untuk menangkap nilai dengan mengurangi sampah dan mendukung penciptaan nilai lokal. Pertimbangkan, misalnya, Zeta, aplikasi berkebun internet gamified di mana aspek advanced berpotensi sangat terukur. Namun, zone budidaya Zeta terletak di daerah pedesaan di Austria dan setelah dipanen buah-buahan dan sayuran dikemas dan dikirim ke pelanggan. Dalam model bisnis ini, skalabilitas penangkapan nilai ditingkatkan melalui pendekatan computerized mereka namun terkendala oleh pertimbangan lingkungan dari penciptaan nilai dalam hal ketersediaan lahan pertanian dan jarak ke konsumen akhir. Demikian pula, Iota menawarkan stage online untuk produk pertanian yang dapat diakses secara advanced dengan hampir tidak ada kendala. Namun, proposisi nilai mereka terbatas pada pemangku kepentingan dalam kedekatan geografis relatif karena pertimbangan $\mathrm{CO} 2$ transportasi sebagai bagian dari penciptaan nilai serta tujuan untuk memberdayakan petani lokal, yang merupakan elemen penting dari penangkapan nilai mereka. Ini dicontohkan melalui kutipan berikut:

"90\% pemasok kami berasal dari dalam radius kurang dari $100 \mathrm{~km}$. Pembelian makanan dengan jarak transportasi pendek dan pertanian organik memberikan kontribusi yang cukup besar terhadap keseimbangan iklim. Pada saat yang sama, perekonomian daerah dan produsen kecil dari daerah sekitarnya diperkuat." (Iota).

\section{DISKUSI DAN IMPLIKASI}

\subsection{Menanamkan teknologi digital dalam elementarisme model bisnis berkelanjutan dan ketegangan logika digital yang muncul}

Artikel ini berusaha untuk mendapatkan pemahaman yang lebih mendalam tentang bagaimana pengusaha berkelanjutan menanamkan teknologi advanced dalam model bisnis mereka untuk menumbuhkan penciptaan nilai lingkungan sosial. Ini adalah studi pertama yang menyelidiki logika advanced yang muncul dalam kewirausahaan berkelanjutan. Kami berpendapat bahwa praktik yang diaktifkan oleh logika computerized mendukung keterkaitan logika lingkungan, sosial, dan komersial tetapi juga memerlukan ketegangan. Oleh karena itu, kami berkontribusi secara teoritis dan empiris terhadap pengembangan bidang penelitian baru yang topikal dan ambisius tentang model bisnis berkelanjutan dalam konteks kewirausahaan.

Dalam desain model bisnis yang berkelanjutan menemukan cara mengkalibrasi, menyeimbangkan, dan memadukan nilai adalah upaya utama. Kami menambahkan hal ini dengan menunjukkan bahwa pengusaha berkelanjutan dapat memanfaatkan teknologi computerized untuk mengembangkan proposisi nilai campuran. Penawaran berkelanjutan seringkali tidak memiliki nilai finansial bagi pelanggan karena produk dan layanan berkelanjutan dikaitkan dengan biaya penciptaan nilai yang lebih tinggi daripada rekan-rekan mereka yang kurang berkelanjutan. Literatur tentang perilaku berkelanjutan, bagaimanapun, berpendapat bahwa aspek-aspek seperti waktu, upaya, dan biaya keuangan adalah penentu penting perilaku favorable to lingkungan pelanggan. Temuan kami menunjukkan bahwa penggunaan teknologi computerized secara selektif dapat meningkatkan kenyamanan dan efisiensi, sambil menurunkan biaya dalam konser dengan 
cara hidup yang lebih berkelanjutan, pada akhirnya memberikan proposisi nilai yang lebih seimbang.

Kami juga menawarkan wawasan baru tentang praktik computerized penciptaan nilai pengusaha. Temuan kami menunjukkan komplementaritas yang luas antara nilai-nilai logika sosial (misalnya, pengembangan masyarakat, partisipasi demokrasi, kesetaraan) dan keterjangkauan teknologi computerized dalam elemen penciptaan nilai. Dengan menggabungkan beberapa artefak dan infrastruktur advanced (misalnya, blog, papan, antarmuka media sosial, stage, dll.) mereka menciptakan ruang untuk interaksi komunitas, terlibat dalam kegiatan penciptaan bersama, dan memperluas integrasi pemangku kepentingan. Dengan praktik yang diaktifkan secara advanced ini, pengusaha berkelanjutan mengelola batas-batas bisnis mereka model, menjadikannya lebih dinamis dan terbuka. Selain itu, kami menemukan pendekatan stage menjadi sangat efektif dalam menyatukan beberapa aktor. Hal ini sangat penting untuk model bisnis berkelanjutan, yang penuh dengan upaya tambahan dalam mengelola hubungan eksternal karena mereka perlu memasukkan berbagai pemangku kepentingan yang beragam. Memberlakukan logika advanced meningkatkan konektivitas aktor di seluruh batas geografis dan memungkinkan penciptaan nilai integratif. Kami, dengan demikian, menambah untuk lebih menjalin hubungan antara penciptaan bersama dan desain model bisnis berkelanjutan.

Selain itu, kami mengidentifikasi hubungan sinergis antara aplikasi digital dan model bisnis berkelanjutan yang mengarah pada penangkapan nilai multidimensi. Penelitian yang masih ada pada pengusaha berkelanjutan mengungkapkan kekhawatiran dalam hal skalabilitas model bisnis dan stabilitas keuangan. Kami menambah badan pengetahuan ini dengan memberikan wawasan baru tentang bagaimana pengusaha memanfaatkan teknologi digital untuk meningkatkan skala penangkapan nilai yang dimaksudkan bersama dengan eksploitasi pelengkap dampak. Pelengkap dampak tersebut berteori sangat penting untuk model bisnis berkelanjutan dan kami menunjukkan cara potensial di mana pengusaha berkelanjutan dapat mencapainya. Kami lebih lanjut menunjukkan bahwa teknologi digital dapat memungkinkan pertumbuhan paralel nilai lingkungan dan keuangan sosial. Ini mengurai pentingnya teknologi digital dan fungsi pendukungnya untuk model bisnis berkelanjutan. Namun, temuan juga mengungkapkan bahwa potensi skalabilitas ini dapat bertentangan dengan logika sosial dan lingkungan. Pengusaha sampel kami sering secara sadar membatasi konektivitas dan aksesibilitas yang disediakan oleh teknologi digital karena pertimbangan yang melibatkan pengurangan $\mathrm{CO} 2$ dan dukungan masyarakat setempat. Dengan demikian, ada indikasi yang menunjuk ke arah potensi ketegangan antara logika dan manifestasinya dalam komponen model bisnis. Sebagai penelitian kami menambah literatur yang menyelidiki kombinasi menantang dari beberapa logika dalam model bisnis dan memeriksa bagaimana logika memungkinkan dan membatasi upaya untuk keberlanjutan.

Kami selanjutnya mengidentifikasi efek tumpahan nilai. Melalui artefak computerized pengusaha menciptakan kesadaran dan nilai pendidikan, yang berarti bahwa penangkapan nilai sosio environmental mereka belum tentu terikat dengan penjualan produk dan layanan inti mereka. Dengan demikian, mereka melanggar batas-batas konvensional model bisnis. Berdasarkan hal ini dan berdasarkan gagasan tumpahan gerakan sosial, kami berpendapat bahwa komunitas online yang terbentuk dan konten yang disediakan dan/atau diciptakan dalam komunitas ini tidak terbatas pada pemangku kepentingan yang terlibat langsung dalam penciptaannya. Isi advanced tidak ada dalam vakum melainkan mempengaruhi individu dan kelompok lain. Hasil kami menunjukkan bahwa sarana advanced memungkinkan untuk memobilisasi dan menghubungkan individu yang dapat mengakibatkan efek tumpahan. Kami, dengan demikian, menawarkan wawasan baru tentang bagaimana teknologi computerized dapat dimanfaatkan untuk mempengaruhi pemangku kepentingan untuk mendukung sosial dan dampak lingkungan.

\subsection{Implikasi teoritis}

Artikel ini menambah pengembangan teoritis model bisnis berkelanjutan yang dikonsep sebagai kombinasi dari berbagai komponen yang memanifestasikan logika kelembagaan plural. Penelitian sebelumnya di bidang ini sebagian besar berfokus pada logika kelembagaan keberlanjutan dan dengan demikian mempertimbangkan bagaimana logika lingkungan, sosial, dan komersial berhubungan satu sama lain. Namun, ini dapat berpotensi meninggalkan logika lebih 
lanjut yang relevan untuk konteks khusus ini. Kami menambah wacana ini dengan membahas pengaruh logika computerized yang muncul pada penciptaan nilai sosio environmental model bisnis berkelanjutan. Kami menggali bagaimana logika computerized yang didasarkan pada konektivitas, keterbukaan, aksesibilitas, dan generativitas berkaitan dengan logika terkait lainnya dalam model bisnis yang berkelanjutan dan mengidentifikasi komplementaritas dan ketegangan. Dengan demikian, ini juga merupakan salah satu studi pertama yang tidak bergantung pada hubungan dikotomi dari dua logika tetapi lebih bertujuan untuk menggabungkan beberapa logika untuk memperluas perspektif pada model bisnis berkelanjutan.

Kami selanjutnya menambah aliran penelitian yang muncul di bidang kewirausahaan yang berupaya menggabungkan keberlanjutan dan digitalisasi. Kami berkontribusi membangun fondasi untuk kewirausahaan berkelanjutan advanced ini. Pertama, kami menunjukkan bahwa perspektif logika kelembagaan pada model bisnis berkelanjutan dapat memberikan fondasi teoritis umum untuk mempelajari persimpangan aliran penelitian yang sebelumnya terpisah ini. Selain itu, memberikan panduan analisis untuk mempelajari upaya pengusaha berkelanjutan menyeimbangkan penciptaan nilai lingkungan, sosial, dan komersial di time computerized. Kedua, tema yang diidentifikasi membuka jalur kaya untuk memajukan hubungan antara aliran penelitian lain seperti penciptaan bersama atau teori gerakan sosial dan berkelanjutan kewirausahaan. Secara khusus, kami berkontribusi pada pengembangan teoritis kewirausahaan berkelanjutan dengan menghadirkan konsep esteem overflow. Tumpahan nilai menarik perhatian pada penangkapan nilai sosio environmental (misalnya, pendidikan dan meningkatkan kesadaran) yang melampaui pelanggan yang ditargetkan dan mempengaruhi kelompok tambahan. Secara khusus, tumpahan nilai ditambah dengan peran teknologi advanced untuk memungkinkan pembentukan komunitas, kegiatan penciptaan bersama, dan integrasi pemangku kepentingan yang lebih luas menawarkan perspektif baru tentang penciptaan nilai kewirausahaan untuk keberlanjutan.

\subsection{Implikasi praktis}

Teknologi advanced secara substansial dapat berkontribusi pada tujuan pembangunan berkelanjutan. Namun, bagaimana potensi ini dapat diwujudkan dalam praktiknya masih sebagian besar belum diketahui, terutama bagi pengusaha yang berupaya menciptakan nilai sosio environmental melalui model bisnis yang layak secara finansial. Artikel ini memberi praktisi wawasan penting tentang bagaimana teknologi advanced dapat disematkan dalam desain model bisnis yang berkelanjutan. Dengan demikian, praktisi dapat memanfaatkan konfigurasi komponen model bisnis berkelanjutan yang diidentifikasi (yaitu, proposisi nilai campuran, penciptaan nilai integratif, dan penangkapan nilai multidimensi) sebagai titik awal yang menginspirasi untuk mengembangkan model bisnis berkelanjutan baru. Misalnya, mereka dapat menarik pentingnya sarana computerized untuk pembentukan komunitas yang menyalurkan banyak kontribusi individu dan upaya banyak aktor menuju tujuan bersama. Ini, pada gilirannya, dapat memanfaatkan penciptaan nilai sosio environmental melalui kegiatan penciptaan bersama dan menyebabkan efek tumpahan dalam elemen penangkapan nilai. Contoh ini menunjukkan potensi tema yang diidentifikasi untuk praktikum tetapi juga menunjuk ke arah hubungan kompleks yang harus diperhatikan praktisi ketika merancang model bisnis yang berkelanjutan.

Menciptakan model bisnis yang layak yang menyelaraskan sejumlah besar sistem nilai yang berbeda sulit dan teknologi advanced tidak dapat menyelesaikan ini sepenuhnya. Terlepas dari komplementaritas yang dilaporkan, praktisi juga harus menyadari ketegangan yang diidentifikasi dalam artikel ini. Solusi advanced meningkatkan konektivitas dan aksesibilitas, tetapi ini dapat menangkal aspirasi lingkungan dan sosial. Teknologi computerized, dengan demikian, bukan obat mujarab untuk pembangunan berkelanjutan dan harus digunakan secara bertanggung jawab, menjaga potensi kontradiksi logika dalam pikiran. Membangun ini, kami merekomendasikan pendekatan yang kritis tetapi tidak inclination ketika merenungkan integrasi sarana computerized untuk meningkatkan dampak model bisnis yang berkelanjutan. 


\section{KETERBATASAN PENELITIAN DI MASA DEPAN}

Artikel ini memiliki keterbatasan yang dapat memberikan fondasi untuk penelitian di masa depan. Pendekatan penelitian kualitatif diterapkan berusaha untuk mendapatkan wawasan baru yang dapat ditransfer ke konteks lain. Kami berpendapat bahwa tema yang diidentifikasi bukan semata-mata khusus dari kasus sampel di tangan tetapi abstraksi yang dapat ditransfer yang dapat memajukan penelitian tentang keberlanjutan dan digitalisasi secara umum. Namun demikian, penelitian di masa depan juga dapat menerapkan pendekatan kuantitatif yang membangun dan memperluas temuan kami. Analisis klaster, misalnya, bermanfaat untuk mengidentifikasi konteks pola model bisnis spesifik. Selanjutnya, kami mengeksplorasi model bisnis pada titik waktu tertentu. Studi longitudinal akan menarik untuk memeriksa apakah dan bagaimana bisnis berkelanjutan berubah dari waktu ke waktu karena teknologi computerized.

Kami juga mendesak mereka yang terlibat dalam upaya penelitian di masa depan untuk menyelidiki tantangan spesifik yang muncul dari menggabungkan logika sosial, lingkungan, dan computerized. Meskipun digitalisasi memberikan potensi yang menjanjikan untuk secara substansial berkontribusi dalam mengurangi tantangan besar saat ini, jalur menuju peningkatan digitalisasi juga dapat memiliki efek negatif yang parah. Dari perspektif sosial, misalnya, itu mengubah rasi bintang pasar tenaga kerja secara signifikan, dan dari perspektif ekologis, peningkatan konsumsi energi bisa sangat besar. Sementara kami dapat mengidentifikasi dan mendiskusikan beberapa kemungkinan ketegangan, kami perlu studi tambahan untuk pemahaman yang lebih rinci tentang hubungan antara keberlanjutan dan digitalisasi. Mengidentifikasi ketegangan sangat penting untuk penelitian tentang kewirausahaan berkelanjutan dan model bisnis.

\section{KESIMPULAN}

Penelitian ini bertujuan untuk mengetahui pengaruh model bisnis untuk meningkatkan nilai sosial terhadap lingkungan. Berdasarkan hasil analisis, maka kesimpulan yang dapat diambil dari penelitian ini adalah bahwa visioner bisnis menggunakan kemajuan terkomputerisasi untuk menciptakan insentif campuran bagi mitra mereka. Untuk mulai dengan, alasan komputerisasi memungkinkan untuk mengkatalisis penciptaan harga sosio environmental dan kedua, memberdayakan visioner bisnis untuk mendirikan penawaran yang mengkonsolidasikan ekologi, sosial, dan penghargaan moneter untuk mitra mereka. 


\section{DAFTAR PUSTAKA}

[1] Gast, J., Gundolf, K., Cesinger, B., 2017. Doing business in a green way: a systematic review of the ecological sustainability entrepreneurship literature and future research directions. J. Clean. Prod. 147, 44e56.

[2] Bocken, N.M.P., Short, S.W., Rana, P., Evans, S., 2014. A literature and practice review to develop sustainable business model archetypes. J. Clean. Prod. 65, 42e56z.

[3] De Clercq, D., Voronov, M., 2011. Sustainability in entrepreneurship: a tale of two logics. Int. Small Bus. J. 29, 322e344.

[4] George, G., Merrill, R.K., Schillebeeckx, S.J.D., 2020. Digital sustainability and entrepreneurship: how digital innovations are helping tackle climate change and sustainable development. Enterpren. Theor. Pract. 104225871989942.

[5] Suyanto, M. (2005). Pengantar Teknologi Informasi Untuk Bisnis. Penerbit Andi.

[6] Manurung, L. (2010). Strategi dan inovasi model bisnis meningkatkan kinerja usaha: Studi empiris industri penerbangan Indonesia. Elex Media Komputindo.

[7] Demil, B., Lecocq, X., 2015. Crafting an innovative business model in an established company: the role of artifacts. In: Business Models and Modelling (Advances in Strategic Management, vol. 33. Emerald Group Publishing Limited, pp. 31e58.

[8] Evans, S., Vladimirova, D., Holgado, M., Van Fossen, K., Yang, M., Silva, E.A., Barlow, C.Y., 2017. Business model innovation for sustainability: towards a unified perspective for creation of sustainable business models. Bus. Strat. Environ. 26, 597e608.

[9] George, G., Merrill, R.K., Schillebeeckx, S.J.D., 2020. Digital sustainability and entrepreneurship: how digital innovations are helping tackle climate change and sustainable development. Enterpren. Theor. Pract. 104225871989942.

[10] Hinings, B., Gegenhuber, T., Greenwood, R., 2018. Digital innovation and transformation: an institutional perspective. Inf. Organ. 28, 52e61.

[11] Hijriati, E., \& Mardiana, R. (2014). Pengaruh ekowisata berbasis masyarakat terhadap perubahan kondisi ekologi, sosial dan ekonomi di Kampung Batu Suhunan, Sukabumi. Jurnal Sosiologi Pedesaan, 2(3), 146-159.

[12] Friedland, R., 2018a. Moving institutional logics forward: emotion and meaningful material practice. Organ. Stud. 39, 515e542.

[13] Friedland, R., 2018b. What good is practice?: ontologies, teleologies and the problem of institution.M@n@gement 21,1357.

[14] Autio, E., Nambisan, S., Thomas, L.D.W., Wright, M., 2018. Digital affordances, spatial affordances, and the genesis of entrepreneurial ecosystems. Strateg. Entrep. J. 12, 72e95.

[15] Corley, K.G., 2015. A commentary on "what grounded theory is....". Organ. Res. Methods $18,600 \mathrm{e} 605$. 
[16] Laasch, O., 2018. Beyond the purely commercial business model: organizational value logics and the heterogeneity of sustainability business models. Long. Range Plan. 51, $158 \mathrm{e} 183$.

[17] Casadesus-Masanell, R., Ricart, J.E., 2010. From strategy to business models and onto tactics. Long. Range Plan. 43, 195e215.

[18] Prahalad, C. K., \& Ramaswamy, V. (2004). The future of competition: Co-creating unique value with customers. Harvard Business Press.

[19] Shah, M. A., Fauziah, M. S., AR, A. M., SS, S. S., Mohammad, N. B., \& Muhammad, B. M. (2014). Analisis statistik kesahan dan kebolehpercayaan soal selidik Skala Konsep Kendiri Multi Dimensi (SKKM). Jurnal Psikologi Malaysia, 12-35.

[20] Ariyani, Y. D., \& Wangid, M. N. (2016). Pengembangan Bahan Ajar Tematik-Integratif Berbasis Nilai Karakter Peduli Lingkungan dan Tanggung Jawab. Jurnal Pendidikan Karakter, (1).

[21] Davies, I.A., Chambers, L., 2018. Integrating hybridity and business model theory in sustainable entrepreneurship. J. Clean. Prod. 177, 378e386.

[22] Laasch, O., 2018. Beyond the purely commercial business model: organizational value logics and the heterogeneity of sustainability business models. Long. Range Plan. 51, $158 \mathrm{e} 183$.

[23] Puteri Wangsa, S., \& Hasanah, U. (2018). Integrasi Teknologi Digital Dalam Pembelajaran Di Era Industri 4.0. Jurnal Tatsqif, 16(1), 42-54.

[24] de Groot, J.I.M., Steg, L., 2009. Mean or green: which values can promote stable pro environmental behavior? Conserv. Lett. 2, 61e66.

[25] Dora, Y. M. (2015, March). PERAN PENCIPTAAN NILAI PRODUK CROCHET DAN SULAM TANGAN UNTUK KEUNGGULAN BERSAING BERKELANJUTAN DI ERA MEA 2015. Seminar Nasional, Universitas Widyatama.

[26] Basharuddin, N. C., Kuspriyanto, K., Saefudin, D., Rakhman, E., \& Ramadlan, A. M. (2014, November). Simulasi Sistem Pembantu Penyalipan Berbasis Logika Fuzzy. In Prosiding Industrial Research Workshop and National Seminar (Vol. 5, pp. 184-190).

[27] Fitriani, A. (2013). Pengaruh kinerja lingkungan dan biaya lingkungan terhadap kinerja keuangan pada BUMN. Jurnal Ilmu Manajemen (JIM), l(1).

[28] Putri, N. A. (2011). Penanaman nilai-nilai pendidikan karakter melalui mata pelajaran sosiologi. Komunitas: International Journal Of Indonesian Society and Culture, 3(2).

[29] Laasch, O., 2018. Beyond the purely commercial business model: organizational value logics and the heterogeneity of sustainability business models. Long. Range Plan. 51, $158 \mathrm{e} 183$.

[30] Priyani, R. (2007). Pluralitas dalam Teori Perencanaan. Journal of Regional and City Planning, 18(3), 23-37.

[31] Juliawati, N. (2018). Membangun kewirausahaan: Antara digital economy dan human economy. 
ISSN: 2723-5262

Online ISSN: 2723-5270

[32] Tohadi, T., Fania, F., \& Gandhi, D. (2019). Problem Teoritik Dan Implikasi Praktis Atas Perubahan Keputusan Tata Usaha Negara. Jurnal Hukum IUS QUIA IUSTUM, 26(3), 500521. 